\title{
Determination of Potential Runoff Coefficient using Geographic Information System for a Small Basin in Balakayety Watershade, Kurdistan Region of Iraq
}

\author{
Jehan M. Fattah Sheikh Suleimany \\ Department of Water Resource Engineering, College of Engineering, Salahaddin University, Erbil, Kurdistan Region, Iraq
}

\author{
*Corresponding author: \\ Jehan M. Fattah Sheikh \\ Suleimany, \\ Department of Water \\ Resource Engineering, \\ College of Engineering, \\ Salahaddin University, Erbil, \\ Kurdistan Region, Iraq. \\ E-mail: jehanmohammed. \\ sheikhsuleimany@su.edu.krd
}

Received: 10 March 2020

Accepted: 13 May 2020

Published: 30 December 2020

DOI

10.25156/pti.v10n2y2020.pp38-43

\section{A B S T R A C T}

Runoff coefficient is an index for losses in rainfall required in most hydrological models and water resources projects. Generally, in the Balakayety water shade in Kurdistan region of Iraq, no runoff data are available as almost basins are ungagged. The Geographic Information System (GIS) techniques and available data for a small basin in Balakayety watershed within the Erbil governorate (Kurdistan Region of Iraq) were used to estimate the coefficient of potential runoff coefficient (PRC). The estimated PRC will be then used to calculate the depth of runoff. The Satellite Imagery (Landsat 7 ETM +) for 2015 was procured to create land cover classes, the classifications accuracy equal to $88.4 \%$, and the Kappa index is $83.7 \%$. The slope map developed from the digital elevation model with $30 \mathrm{~m}$ resolution. The area's hydrologic soil map is digitized from the Iraqi soil map. The inverse distance weighting method was used to interpolate the rainfall of the study area into the Arc GIS. It was found that the most study area covered by moderate to high (PRC) values ranged from $55 \%$ to $83 \%$, and runoff depth values vary from $398.1 \mathrm{~mm}$ to $610.3 \mathrm{~mm}$. The present study indicates that the integration of all obtained thematic maps into GIS provides a powerful tool for calculating the runoff coefficient for catchments lacks streamflow data which can result in flood/drought predictions that will be not accurate. These findings are helpful in identifying flood areas, selecting proper sites for water harvesting, and enhancing water resources management programs.

Keywords: Geographic information system; Land cover; Runoff coefficient; Slope map; Soil data

\section{INTRODUCTION}

Runoff coefficient is a dimensionless factor that is used to convert the rainfall to runoff, and it represents the integrated effect of catchment losses and hence depends on the nature of the land surface, slope, degree of saturation, and rainfall intensity (Goel, 2011). These coefficients are useful for understanding the flood frequency controls in a particular hydrologic or climatic regime (Mahmoud et al., 2014). In recent times, using the remote sensing and the Geographic Information Systems (GIS) have appeared in almost articles to estimate watershed runoff coefficient as Shadeed and Almasri, 2010, Mahmoud et al., 2014, Mahmoud, 2014, Nasiri and Alipur, 2014, Ahmad et al., 2015, and Hameed, 2013. All of the aforementioned researchers integrated soil data, land use, slope, and rainfall intensity in a GIS environment to estimate runoff, runoff coefficient, and runoff depths. They used a linear equation of runoff coefficient and surface slope developed by Liu and De Smedt (2004) or the soil (SCS-CN) method developed by the United States department of agriculture (USDA,1986) and pre-prepared tables by Liu and De
Smedt 2004 for different catchments in Palestine, Saudi Arabia, Egypt, Iran, India, and Iraq, respectively. In the present study, a small basin of $57.6 \mathrm{~km}^{2}$ area was selected. It represents a rugged mountainous area that has elevation ranges from 1138 to $3347 \mathrm{~m}$, located in the north-eastern part of Iraq in the Erbil Government (Kurdistan Region). The main goal of this study is to determine the runoff coefficient and the runoff depth in the study area which lacks streamflow measurements. The analysis involves processing spatial data (Landsat 7 ETM+), DEM, land cover, soil texture, rainfall, and slope maps using (GIS) tools.

\section{MATERIALS AND METHODS}

\section{Study Area Illustration}

Geographically, the study area located in the north-eastern part of Iraq within Erbil Government (Kurdistan Region), lying between $\left(36^{\circ} 44^{\prime} 0.00^{\prime \prime}\right.$ to $36^{\circ} 42^{\prime} 68^{\prime}$ 'Northern Latitude and $44^{\circ} 48^{\circ}$ to $44^{\circ} 50^{\circ}$ Eastern Longitude) and has $56.7 \mathrm{~km}^{2}$ area. Its mountain areas characterized by shallow lithosolic soils in limestone, steep slopes, rock outcrop, 
and deep valleys have a Mediterranean climate region with plenty of rains (Buringh, 1960). Figure 1 shows the location map of the study area.

\section{Digital Elevation Model (DEM) and Slope Map}

Satellite Imagery (Landsat 7 ETM+) for the year 2015 with $30 \mathrm{~m}$ resolution was imported from the USGS website into the Arc GIS software and displayed as 5, 4, and 3 (RGB) composite. The image geo-referenced, according to UTM WGS84_38N, projected coordinate systems (metric). All sink areas were filled using Arc GIS, and a $30 \mathrm{~m}$ DEM was obtained. The DEM is used for watershed delineation, including streams, outlets, and inlets definitions. The slope map was then generated. Figure 2 illustrates the DEM for the considered study area.

\section{Soil Data}

The study area is located at Zagroz Thrust Zone (Nappe), which has Naopurdan-Walash Series and Qandil (Metamorphic) Series formations which are semipermeable to impermeable layers and most precipitation runoff (Buringh, 1960; Fouad and Sissakian, 2015; Sissakian, 2018). In general, the landscapes have shallow brown lithosolic soils in limestone, and soil that does develop is regularly washed down the hillsides into the valleys below. By digitization, the soil data were extracted using Arc GIS tools, and the hydrological soil map (hydrologic soil groups [HSG]) was generated as per the standard norms given in chapter 7 of the National Engineering Handbook (Natural Resources Conservation Service, 2009).

\section{Land Cover}

Land cover/land use has a significant influence on infiltration and hence on the runoff coefficient (Sharma, 1986). For the image classification process to be successfully, several factors should be considered, including the availability of quality Landsat imagery and secondary data, a precise classification process, and user's experiences and expertise of the procedures (Rwanga and Ndambuki, 2017). Supervised classification methods, with maximum likelihood clustering in ArcGIS Spatial Analyst extension, were applied to the (Landsat 7 ETM+) for 2015 for the study area to develop the land cover map classes.

\section{Accuracy Assessment and Kappa Index for Image Classification}

Accuracy assessment and Kappa index mean to compare the classified image to another data source that is considered to be accurate or ground truth data. This process uses three geoprocessing tools in Arc Map: Create Accuracy Assessment Points, Update Accuracy Assessment Points, and Compute Confusion Matrix. (Cohen, 1960).

\section{Potential Runoff Coefficient (PRC)}

The soil texture, land cover classes, and the slop map of the required area in this study were merged in ArcGIS as one map. Then, the PRC is estimated by applying a linear equation relating the runoff coefficient to the slope, as shown in Eq. (1) (Liu and De Smedt, 2004).

$$
\mathrm{C}=\mathrm{C}_{\mathrm{o}}+\left(1-\mathrm{C}_{\mathrm{o}}\right) \frac{\mathrm{S}}{\mathrm{S}+\mathrm{S}_{\mathrm{o}}}
$$

Where, $\mathrm{C}$ is the PRC for a surface slope S (\%), $\mathrm{C}_{\mathrm{o}}$ is the PRC for the near-zero slopes in reference to the first row of every land use class in the PRC values for different land use, slope, and soil texture, which are taken from Table 1. The data in Table 1 are published by Liu and De Smedt, 2004, which are sourced from published materials (Beven and Kirkby 1979, Fetter, 1980, Chow et al., 1988, Browne, 1990, Mallants and Feyen, 1990, and Mahmoud, 2014). Furthermore, the $\mathrm{S}_{\mathrm{o}}(\%)$ is a slope constant for different land use and soil type, their values are given in Table 2 (Liu and De Smedt, 2004). Figure 3 demonstrates the conceptual framework for runoff coefficient mapping.

\section{Rainfall and Runoff Depth}

Average of monthly rainfall data around the study area for 4 years (2012-2015) was obtained from four precipitation

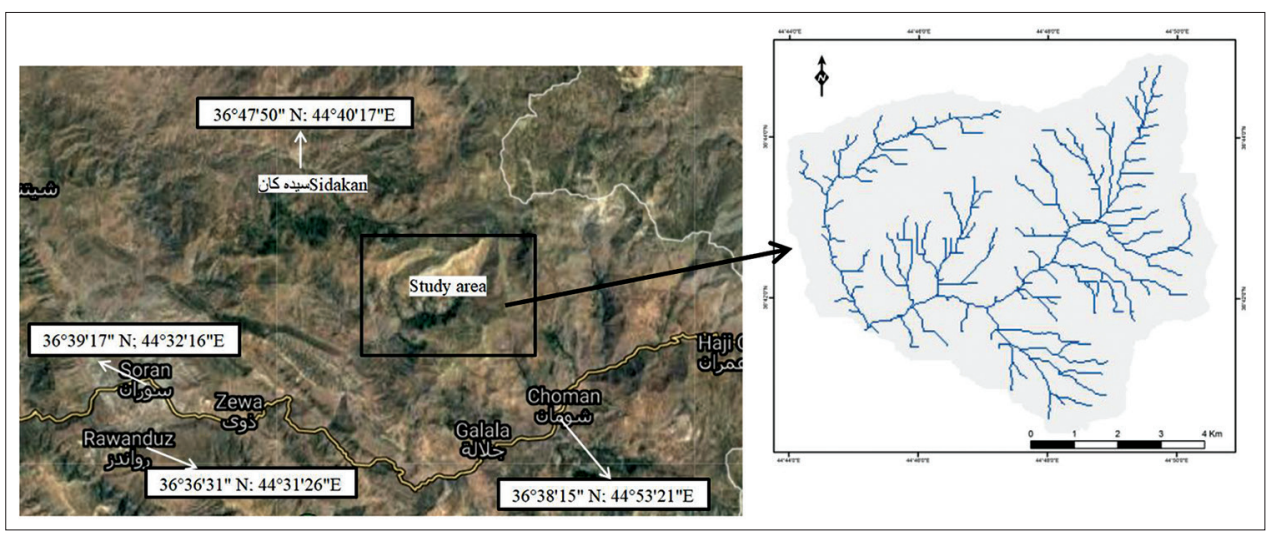

Figure 1: Illustration map of the study area 
Table 1: PRC (Liu and De Smedt, 2004)

\begin{tabular}{|c|c|c|c|c|c|c|c|c|c|c|c|c|c|}
\hline Land use & Slope (\%) & Sand & $\begin{array}{l}\text { Loamy } \\
\text { sand }\end{array}$ & $\begin{array}{l}\text { Sandy } \\
\text { loam }\end{array}$ & Loam & $\begin{array}{l}\text { Silt } \\
\text { loam }\end{array}$ & Silt & $\begin{array}{c}\text { Sandy } \\
\text { clay loam }\end{array}$ & $\begin{array}{l}\text { Clay } \\
\text { loam }\end{array}$ & $\begin{array}{l}\text { Silty clay } \\
\text { loam }\end{array}$ & $\begin{array}{l}\text { Sandy } \\
\text { clay }\end{array}$ & $\begin{array}{l}\text { Silty } \\
\text { clay }\end{array}$ & Clay \\
\hline \multirow[t]{4}{*}{ Forest } & 1.5 & 0.03 & 0.07 & 0.10 & 0.13 & 0.17 & 0.20 & 0.23 & 0.27 & 0.30 & 0.33 & 0.37 & 0.40 \\
\hline & $0.5-5$ & 0.07 & 0.11 & 0.14 & 0.17 & 0.21 & 0.24 & 0.27 & 0.31 & 0.34 & 0.37 & 0.41 & 0.44 \\
\hline & $5-10$ & 0.13 & 0.17 & 0.20 & 0.23 & 0.27 & 0.30 & 0.33 & 0.37 & 0.40 & 0.43 & 0.47 & 0.50 \\
\hline & $>10$ & 0.25 & 0.29 & 0.32 & 0.35 & 0.39 & 0.42 & 0.45 & 0.49 & 0.52 & 0.55 & 0.59 & 0.62 \\
\hline \multirow[t]{4}{*}{ Grass } & $<0.5$ & 0.13 & 0.17 & 0.20 & 0.23 & 0.27 & 0.30 & 0.33 & 0.37 & 0.40 & 0.43 & 0.47 & 0.50 \\
\hline & $0.5-5$ & 0.17 & 0.21 & 0.24 & 027 & 0.31 & 0.34 & 0.37 & 0.41 & OA4 & 0.47 & 0.51 & 0.54 \\
\hline & $5-10$ & 0.23 & 0.27 & 0.30 & 0.33 & 0.37 & 0.40 & 0.43 & 0.47 & 0.50 & 0.53 & 0.57 & 0.60 \\
\hline & $>10$ & 0.35 & 0.39 & 0.42 & 0.45 & 0.49 & 0.52 & 0.55 & 0.59 & 0.62 & 0.65 & 0.69 & 0.72 \\
\hline \multirow[t]{4}{*}{ Crop } & 1.5 & 0.23 & 0.27 & 0.30 & 0.33 & 0.37 & 0.40 & 0.43 & 0.47 & 0.50 & 0.53 & 0.57 & 0.60 \\
\hline & $0.5-5$ & 0.27 & 0.31 & 0.34 & 0.37 & 0.41 & 0.44 & 0.47 & 0.51 & $0.5-1$ & 0.57 & 0.61 & 0.64 \\
\hline & $5-10$ & 0.33 & 0.37 & 0.40 & 0.43 & 0.47 & 0.50 & 0.53 & 0.57 & 0.60 & 0.63 & 0.67 & 0.70 \\
\hline & $>10$ & 0.45 & 0.49 & 0.52 & 0.55 & 0.59 & 0.62 & 0.65 & 0.69 & 0.72 & 0.75 & 0.79 & 0.82 \\
\hline \multirow[t]{4}{*}{ Bare soil } & $<0.5$ & 0.33 & 0.37 & 0.40 & OA3 & 0.47 & 0.50 & 0.53 & 0.57 & 0.60 & 0.63 & 0.67 & 0.70 \\
\hline & $0.5-5$ & 0.37 & 0.41 & 0.44 & 0.47 & 0.51 & 0.54 & 0.57 & 0.61 & 0.64 & 0.67 & 0.71 & 0.74 \\
\hline & $5-10$ & 0.43 & 0.47 & 0.50 & 0.53 & 0.57 & 0.60 & 0.63 & 0.67 & 0.70 & 0.73 & 0.77 & 0.80 \\
\hline & $>10$ & 0.55 & 0.59 & 0.62 & 0.65 & 0.69 & 0.72 & 0.75 & 0.79 & 0.82 & 0.85 & 0.89 & 0.92 \\
\hline $\mathrm{Mp}$ & & 1.00 & 1.00 & 1.00 & 1.00 & 1.00 & 1.00 & 1.00 & 1.00 & 1.00 & 1.00 & 1.00 & 1.00 \\
\hline
\end{tabular}

PRC: Potential runoff coefficient

Table 2: Slope Constant (Liu and De Smedt, 2004)

\begin{tabular}{|c|c|c|c|c|c|c|c|c|c|c|c|c|}
\hline \multirow{3}{*}{ Land use } & \multirow{3}{*}{ Sand } & \multirow{3}{*}{$\frac{\text { Loamy }}{\text { Sand }}$} & \multirow{3}{*}{$\begin{array}{l}\text { Sandy } \\
\text { Loam }\end{array}$} & \multirow{3}{*}{ Loam } & \multirow{3}{*}{$\begin{array}{c}\text { Sill } \\
\text { Loam }\end{array}$} & \multirow{3}{*}{ Silt } & \multirow{2}{*}{$\begin{array}{c}\text { Sandy } \\
\text { Clay }\end{array}$} & \multirow{3}{*}{$\begin{array}{c}\text { Clay } \\
\text { Loam }\end{array}$} & \multirow{2}{*}{$\begin{array}{l}\text { Silty } \\
\text { Clay }\end{array}$} & \multirow{3}{*}{$\begin{array}{c}\text { Sandy } \\
\text { Clay }\end{array}$} & \multirow{3}{*}{$\begin{array}{l}\text { Silty } \\
\text { Clay }\end{array}$} & \multirow{3}{*}{ Clay } \\
\hline & & & & & & & & & & & & \\
\hline & & & & & & & Loam & & Loam & & & \\
\hline Forest & 0.680 & 0.650 & 0.620 & 0.590 & 0.560 & 0.530 & 0.500 & 0.470 & 0.440 & 0.410 & 0.380 & 0.350 \\
\hline Grass & 0.580 & 0.551 & 0.522 & 0.493 & $0.46-1$ & 0.435 & 0.405 & 0.376 & 0.347 & 0.318 & 0.29 & 0.260 \\
\hline Crop & 0.500 & 0.471 & 0.442 & 0.413 & $0.38-1$ & 0.355 & 0.325 & 0.296 & 0.267 & 0.238 & 0.209 & 0.180 \\
\hline Bare soil & 0.420 & 0.393 & 0.365 & 0.338 & 0.311 & 0.284 & 0.256 & 0.229 & 0.202 & 0.175 & 0.147 & 0.120 \\
\hline
\end{tabular}

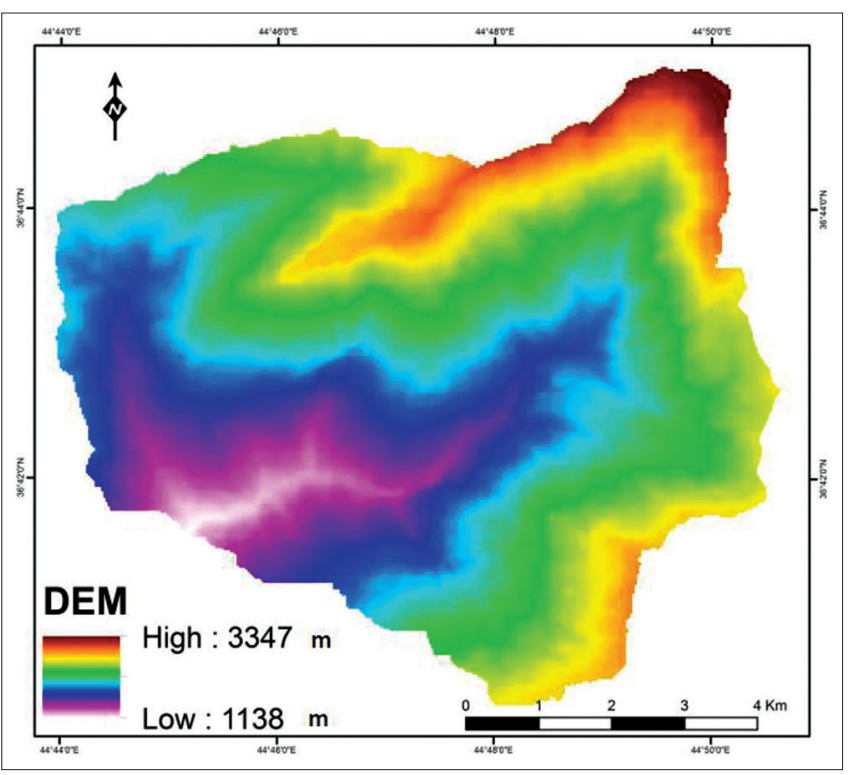

Figure 2: Digital elevation model of the study area

stations: Rawanduz (36³6’31" N; 4431'26'E), Soran (3639'17" N; 4432'16”'E), Choman (36³8'15" N;

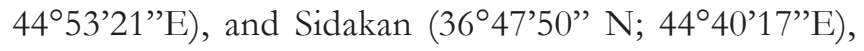
as shown in Figure 1, which is available at the General
Meteorological Director, Erbil (Kurdistan Regional Government. 2015). The rainfall data were interpolated into the Arc Map using the inverse distance weighting method. Using the raster calculator tool, which is provided in the Arc Map toolbox, all estimated (PRC) values from the previous steps were multiplied by the rain falls data, and a runoff depth map is generated. Eq. (2) indicates the percentage of rainfall that is transformed into runoff (Chow et al., 1998).

$$
\text { Runoff coefficient }(C)=\frac{\text { Runoff }(\mathrm{mm})}{\text { Rainfall }(\mathrm{mm})}
$$

\section{RESULTS AND DISCUSSION}

In the present study, the soil texture, land cover classes, rainfall, and surface slope maps have been adopted to estimate the runoff coefficient and runoff depth maps for the study area using GIS tools as follows:

\section{Slope Map}

Figure 4 shows the variation of the steepness of the slope from moderate to steep for the study area. The slope map was classified into three classes, namely gentle $\left(<22.5^{\circ}\right)$, moderate $\left(22.5^{\circ}-45^{\circ}\right)$, and steep $\left(>45^{\circ}\right)$. 


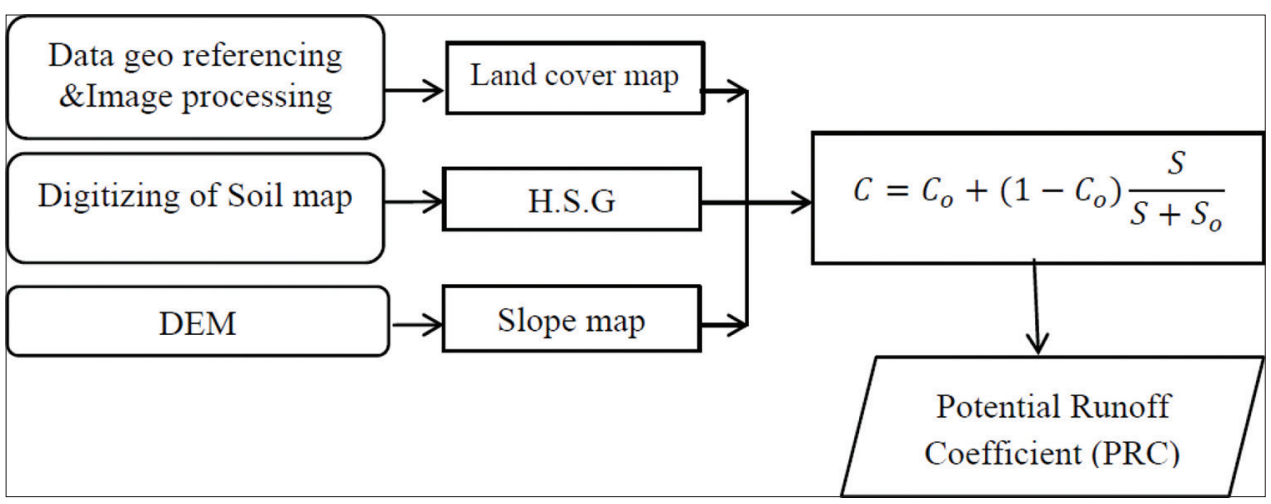

Figure 3: Conceptual framework of PRC mapping

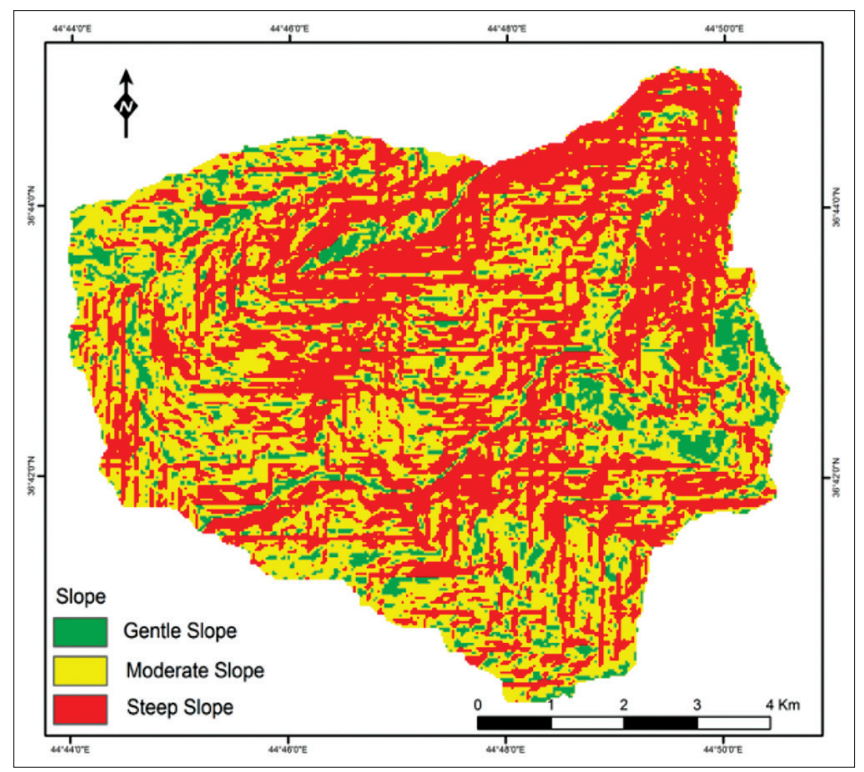

Figure 4: Slop Map of the study area

\section{HSG}

Figure 5 demonstrates the hydrological soil (HSG) map which, according to the Natural Resources Conservation Service (2009) classification for the whole area, is grouped HSG D. The soil texture is a rough mountainous land, loamy to clayey soils with variable stone content, and rock outcrops (Hameed, 2013); Having, a moderate to high runoff potential when thoroughly wet (Maidment, 1993).

\section{Land Cover Classes}

Table 3 illustrates different land cover classes obtained for the area under study using unsupervised classification and maximum likelihood classification function in the ArcGIS. The highest ratio of $57.55 \%$ of the area is covered with grass and forest and $37.2 \%$ of the total dry land area covered by bare soil. The overall classification accuracy was $88.4 \%$, and the Kappa index was $83.7 \%$, which is an excellent agreement, according to Cohen (1960). Figure 6 demonstrates the land cover classes in the study area. From the figure, it can be seen that the runoff value is lowest for

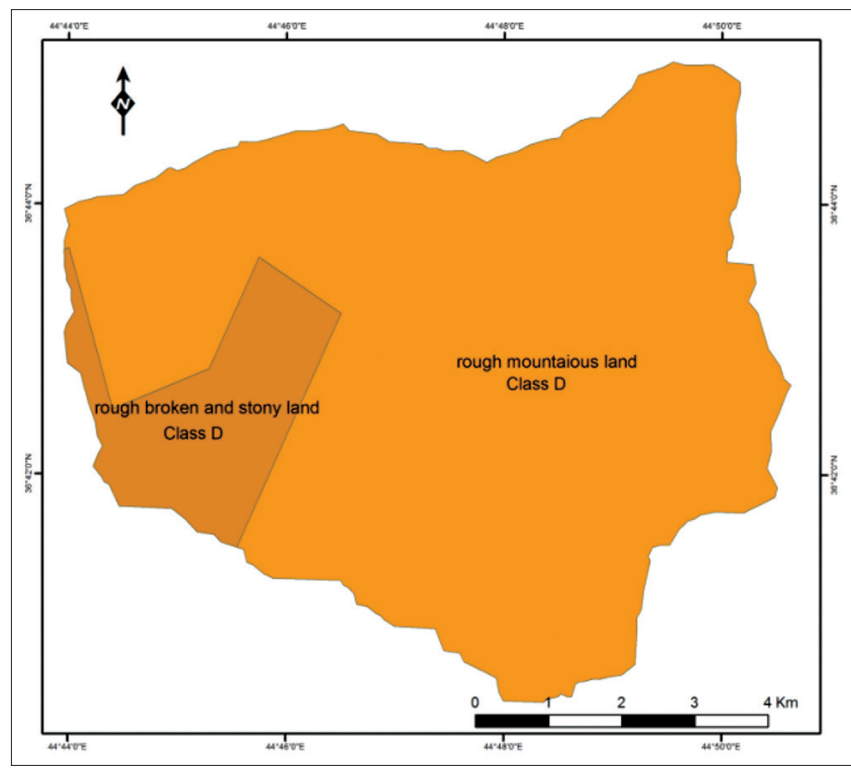

Figure 5: Hydrologic soil groups of the study area

Table 3: Areas covered by different land cover classes

\begin{tabular}{lcc}
\hline Land cover & Area (ha) & Area \% \\
\hline Bare soil & 2143.85 & 37.20 \\
Built up land & 40.66 & 0.71 \\
Water & 1.42 & 0.02 \\
Farmland & 260.8 & 4.52 \\
Grass and open forest & 3316.9 & 57.55 \\
\hline
\end{tabular}

forest and grassland, more for cultivated field crops and higher for bare soils.

\section{PRC}

Figure 7 indicates that the values of estimated runoff coefficients in this study ranged from $55 \%$ to $83 \%$, which are high for lands covered by bare soils as they are impervious, and most precipitation runs off, and moderate for land classes grass and forest. Furthermore, the variations of the PRC values with the surface slope are less. This result confirms the findings of Sharma (1986) and Mahmoud (2014) that the runoff coefficients strongly dependent on land cover and, to a lesser extent, on a water shade slope. 


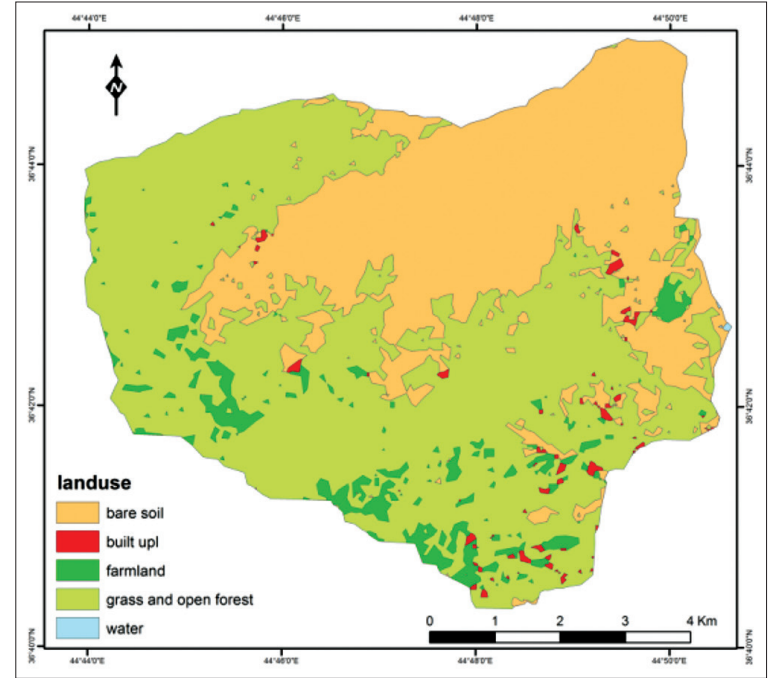

Figure 6: Land cover classes in the study area

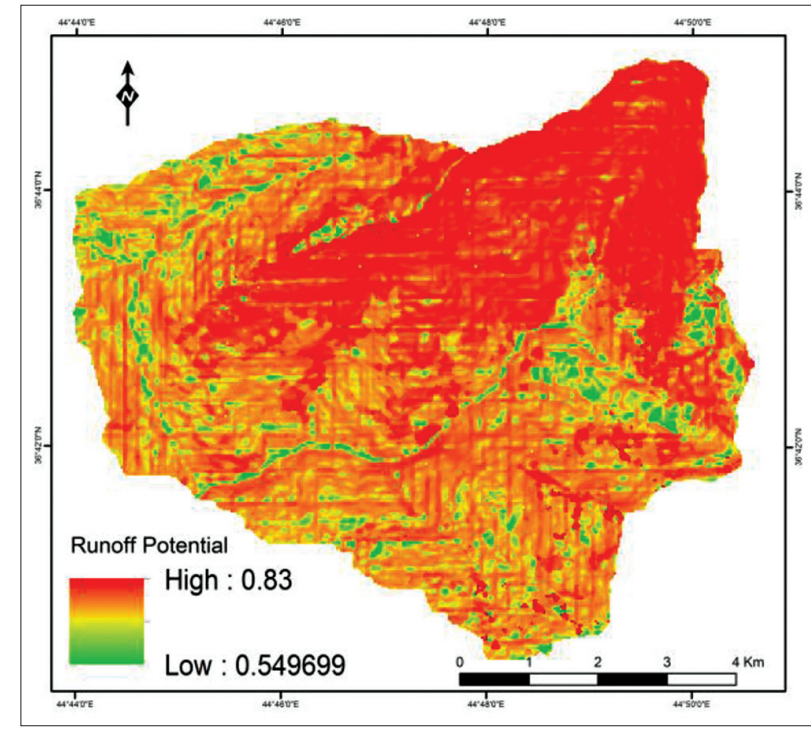

Figure 7: Potential runoff coefficient map for the study area

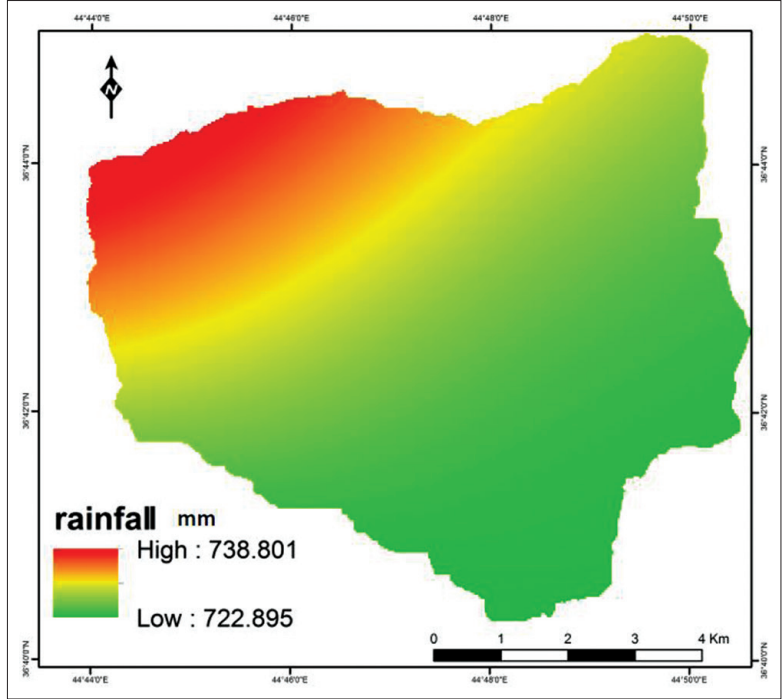

Figure 8: Rainfall distribution map of the study area

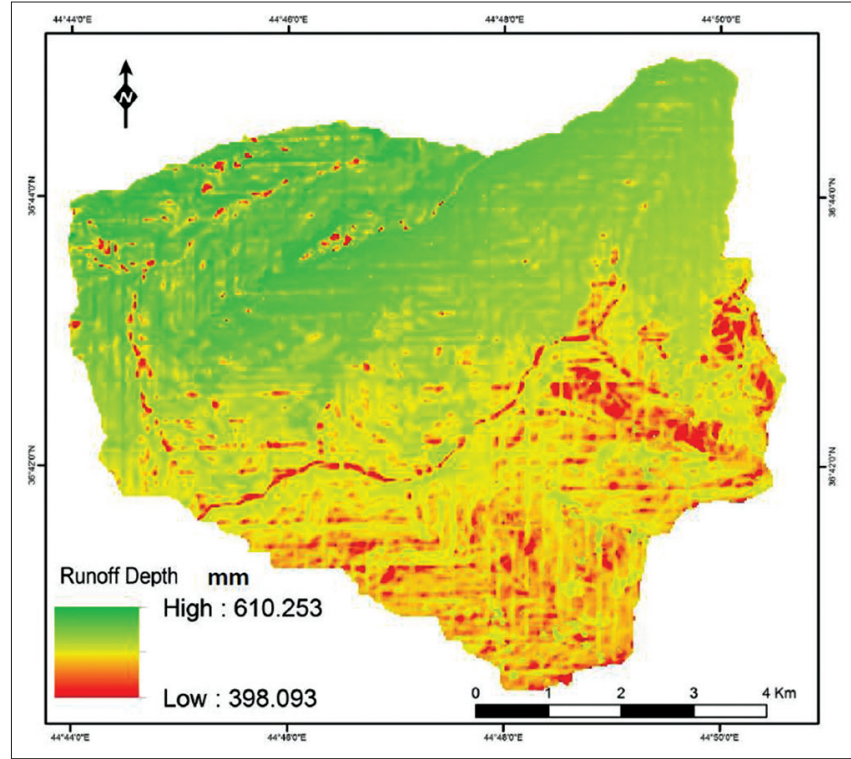

Figure 9: Runoff Depth Map of the study area

\section{Runoff Depth}

Figure 8 indicates that the spatial variability of average rainfall over the study area ranged from 723 to $739 \mathrm{~mm}$. Figure 9 indicates that the estimated average runoff depth increases with increasing the intensity of the precipitation and ranged from 610.3 to $398.1 \mathrm{~mm}$. It is observed that the runoff depth is lowest for forest and grassland, more about cultivating field crops, and higher for bare soils.

\section{CONCLUSIONS}

In the present study, the following conclusions are summarized:

- The study area is rugged terrain and entirely is grouped HSG D. The soil texture is a rough mountainous land, loamy to clayey soils with variable stone content, and rock outcrops. Having a moderate to high runoff potential ranged from $55 \%$ to $83 \%$

- The land cover classes were bare soil, built-up land, grass and forest, water, and farmland. The runoff coefficients were significantly dependent on land cover. It was high for lands covered by bare soils and moderate for grass and forest lands. The overall classifications accuracy and Kappa index were 88.4\% and $83.7 \%$, respectively

- The runoff depth ranged from 610.3 to $398.1 \mathrm{~mm}$ and increased with increasing the intensity of the precipitation. It was lowest for forest and grassland, more about cultivating field crops and higher for bare soils

- Integration of GIS techniques with a linear equation developed by Liu and De Smedt (2004) provides a powerful tool for determining the runoff coefficient for ungagged basins that do not have sufficient 
historical records and can help in mitigating the potential impact of flooding

- The study has helped to visualize the impact of variation in land cover on the runoff volume and can support water harvesting and water resource exploitation projects

- Lack of streamflow data and records in the interesting area has limited the verification of the results.

\section{REFERENCES}

Ahmad, I., V. Verma and M. K. Verma. 2015. Application of Curve Number Method for Estimation of Runoff Potential in GIS Environment. $2^{\text {nd }}$ International Conference on Geological and Civil Engineering, Singapore. p16-20.

Beven, K. J. and M. J. Kirkby. 1979. A physically based, variable contributing area model of basin hydrology/Un modèle à base physique de zone d'appel variable de l'hydrologie du bassin versant. J. Hydrol. Sci. Bull. 24(1): 43-69.

Browne, F. X. 1990. Stormwater management. In: Corbitt, R. A., editor. Standard Handbook of Environmental Engineering. McGraw-Hill Companies, New York.

Buringh, P. 1960. Soils and Soil Conditions in Iraq. Ministry of Agriculture, Baghdad.

Chow, V. T., D. R. Maidment and L. W. Mays. 1988. Applied Hydrology. McGraw-Hill International, New York.

Cohen, J. 1960. A coefficient of agreement for nominal scales. Educ. Psychol. Meas. 20(1): 37-46.

Fetter, C. W. 1980. Applied Hydrogeology. Merill Publishers, Columbus, OH. p488.

Fouad, S. F. and V. K. Sissakian. 2015. Geological Map of Iraq, Scale 1: 1000 000, 2012. Iraqi Bull. Geol. Min. 11(1): 9-16.

Goel, M. K. 2011. Runoff coefficient. In: Encyclopedia of Snow, Ice and Glaciers. Springer Netherlands, Dordrecht. p952-953.

Hameed, H. 2013. Water Harvesting in Erbil Governorate, Kurdistan Region, Iraq: Detection of Suitable Sites using Geographic
Information System and Remote Sensing. Student Thesis Series INES. Lund University, Lund, Sweden.

Kurdistan Regional Government. 2015. Ministry of Transport and Communications. General Meteorological Director, Erbil.

Liu, Y. B. and F. De Smedt. 2004. WetSpa Extension, a GISBased Hydrologic Model for Flood Prediction and Watershed Management. Vrije Universiteit Brussel, Belgium. pe108.

Mahmoud, S. H. 2014. Investigation of rainfall-runoff modeling for Egypt by using remote sensing and GIS integration. Catena. 120: 111-121.

Mahmoud, S. H., F. S. Mohammad and A. A. Alazba. 2014. Determination of potential runoff coefficient for Al-Baha Region, Saudi Arabia using GIS. Arab. J. Geosci. 7(5): 2041-2057.

Maidment, D. R. 1993. Handbook of Hydrology. McGraw-Hill, New York. p397323.

Mallants, D. and J. Feyen. 1990. Quantitative and Qualitative Aspects of Surface and Groundwater Flow in Dutch. Vol. 2. Katholieke Universiteit Leuven, Belgium.

Nasiri, A. and H. Alipur. 2014. Determination the curve number catchment by using GIS and remote sensing. Int. J. Environ. Chem. Ecol. Geol. Geophys. Eng. 8(5): 342-345.

Natural Resources Conservation Service, United States Department of Agriculture. 2009. Hydrologic soil groups. In: National Engineering Handbook. Natural Resources Conservation Service, United States Department of Agriculture, Washington, DC. p7-1.

Rwanga, S. S. and J. M. Ndambuki. 2017. Accuracy assessment of land use/land cover classification using remote sensing and GIS. Int. J. Geosci. 8(4): 611.

Shadeed, S. and M. Almasri. 2010. Application of GIS-based SCS-CN method in West Bank catchments, Palestine. Water Sci. Eng. 3(1): 1-13.

Sharma, S. K. 1986. Irrigation Engineering and Hydraulic Structures. S. Chand Publishing, New Delhi.

Sissakian, V. K. 2018. The minerals wealth in the Kurdistan Region, Iraq. UKH J. Sci. Eng. 2(2): 23-36.

United States Department of Agriculture. 1986. TR-55: Urban Hydrology for Small Watersheds. Technical Release. United States Department of Agriculture, Washington, DC. 